\title{
TRANSLATOR'S NOT'E
}

I

last saw Margarita Khemlin on September 6, 2014, at a translation award ceremony in Moscow. She came to the ceremony to return an amber necklace, a gift she'd made for me a few years before, and then restrung during my time in Moscow-the necklace was such a favorite that I wore through its soft band of leather all too quickly. She handed it to me, telling me she'd fixed it for all time; I thanked her. And then she vanished, emailing later to apologize, though the apology was utterly superfluous because I knew she didn't like ceremony or ceremonies.

Margarita vanished from the earth altogether a little over a year later. I learned of her death on a gray October day and went outside to dig potatoes because fried potatoes make for comforting medicine. And perhaps, too, because she and I had talked about kitchen gardens and vegetables one night in New York City a few years before-the garden still makes me think of her. Although I'd only translated two of Margarita's stories before her death, she was, for the translator in me, a sort of first love. Her "Basya Solomonovna's Third World War" was the first work I chose myself, translated, and 
then published, in Two Lines. I wanted to translate Klotsvog as soon as I read it, too, having loved the voice that Margarita channeled for her title character and first-person narrator, Maya Klotsvog. I'm grateful to Columbia University Press and the Russian Library for supporting my translation of Klotsvog.

Margarita wrote about a vanished Soviet Union, where she was born and lived, and where I first visited in 1983. Klotsvog conjures up a very specific corner of that world, and Maya's language in the novel often includes phrases and vocabulary typical of the Soviet era. The narrative that Margarita creates for Maya is written using the skaz technique, mimicking oral speech in written form. Timing, pauses, momentum, word order, and a myriad of other factors take on tremendous importance in skaz, making it particularly crucial for a translation to capture a narrative voice that's unlikely to sound literarily smooth. Maya's voice is very distinctive: she loves to call herself a pedagogue and sometimes sounds likes a petty bureaucrat, plus she has a way of emoting, in somewhat purple hues, when describing the many twists and turns of her love life.

I can't claim that my English-language rendering of all Maya's tortured phrasings — sometimes she tries a bit too hard to make her speech sound elevated-will evoke in English-language readers the reactions that Maya's original does for Russian readers. Experiences are just too different, though I can say that learning (and later teaching) Russian during Soviet times and using textbooks published in the USSR taught me some of the rhythms and peculiarities of standard, often rather formal language, along with phrases, for example, about cities being "cultural centers" or Soviet peoples standing "shoulder to shoulder." Maya often uses similar types of expressions, so I felt right at home.

As a student, I also learned of institutions like Pioneer Palaces, places where children-Young Pioneers-went for lessons and activities in their leisure time, just as one character does in 
Klotsvog, to work on his checkers game. A note on checkers: the novel includes mentions of the "Chapaev" variation, which involves flicking pieces (this certainly makes it worth looking up online for details!) and is named for Vasily Chapaev, a Red Army commander during the Russian Civil War. Chapaev has other mentions in the novel: there's a Chapaev cinema, and Maya even recalls the film Chapaev - specifically a scene where the White Army mounts a "psychological attack" on the Red Army but is forced to retreat. ${ }^{1}$

There are two other historical references in the book that I'd like to mention briefly. Though neither Pinya Mirochnik nor Menahem Mendel Beilis plays directly into the novel's action, both are part of the antisemitic atmosphere in which Maya lives. Beilis was accused of killing a boy in a blood libel murder in Kiev in 1911 but acquitted in 1913. Pinya Mirochnik, however, was Maya's contemporary, albeit as a figure in a notorious feuilleton that played on xenophobic and antisemitic propaganda themes: In a piece written in 1953 by Vasily Ardamatsky for the satirical newspaper Krokodil, ${ }^{2}$ he was accused of embezzling state property, as well as having relatives overseas. Although the reference to Pinya Mirochnik is, technically, an anachronism in the novel-the scene in which Maya references it predates its publication - this only serves to highlight further the fears that Maya feels during a very stressful time of pervasive antisemitism.

The Beilis accusations from before Maya was born and the Mirochnik accusations from her lifetime-along with the nationality question on official government paperwork-contributed to the survivor's fear that Lara Vapnyar mentions in her beautiful foreword to this book. Her essay offers both historical context and her own, very personal, reactions. I can't thank Lara Vapnyar enough for writing this foreword-it's no exaggeration to say that I couldn't have even dreamed of such a fitting piece, which left me with tears, too-and mentioning the sorts of discoveries that Klotsvog can 
inspire in readers (and in the novel's translator: I'm grateful for the new perspectives her foreword gave me).

So many people played parts over the years in bringing this translation into the world that I can't list everyone and all their help, though I want to list many because noting their contributions will reveal certain technical aspects of the book (without spoiling the story) that readers might like to know about. Christine Dunbar, my editor at Columbia University Press, has been encouraging and patient from start (when I suggested Klotsvog as a potential book for the Russian Library) to finish (when last-minute text issues came up). It's a pleasure to work with an editor in whom in-depth knowledge of Russian, Russian literature, and translation blends so well with both an ear for English and a willingness to allow a translation to be a translation so a book can possess its own very unique textual logic in English.

Anonymous peer reviewers offered very helpful comments that were both tactful and candid. I'm grateful for their assessments of the novel itself, which helped me see Klotsvog from other angles, and of my translation. My Russian colleague Liza Prudovskaya, who has read a draft of every novel I've translated, answered, as usual, hundreds of questions and saved me from at least as many careless mistakes. Other people helped, in various ways, with individual words or lists of words: Olga Bukhina, Ian Dreiblatt, Mikhail Krutikov, and Sean Bye. I'm especially indebted to Olga Radetzkaja, who translated Klotsvog into German, for sharing her correspondence with Margarita: Olga asked Margarita many of the same questions I would have, so her generosity is much appreciated. Michael Klimov helped me translate the Ukrainian speech that comes up in the novel. After much deliberation about how to handle the bits of Ukrainian, I decided to transliterate a few key words, to give a taste of Maya's multilingual environment rather than either erase the Ukrainian completely or break the flow of the skaz narrative too 
much with a lot of transliterated Ukrainian words and footnotes with English translation.

Finally, Margarita's twin sister, Alla Khemlin, and Margarita's husband, Vardvan Varzhapetyan, both helped me tremendously by answering questions and giving me articles and support after Margarita's death. To say it was a bittersweet pleasure to meet with them and Christine in Moscow in September 2018 to talk about the translation feels inadequate because I miss Margarita so much. Margarita, of course, is the person I am most grateful to, both for trusting me with her stories nearly a decade ago, when I was just starting as a translator, and for becoming a friend. Translating Margarita meant serving as one of her voices in English (I'm not her sole English translator; I'm part of a chorus, along with Melanie Moore and Arch Tait) and I can only say that losing an author, particularly someone like Margarita, whom I knew and felt such affection for, has been a deeply heartbreaking experience. I think of her every day and I'm still thankful for her trust, which helped me gain confidence. And then there are her stories, which have taught me so much about writing and life and the world. And then, of course, there's her amber necklace, strengthened for all time and ready to be worn again and again, as a sort of talisman and a reminder of literature, loss, and love.

\section{Notes}

1. As of this writing, in late February 2019, the scene can be viewed on YouTube here: https://www.youtube.com/watch?v=8v9U7v3telo.

Georges Sadoul's 1965 Dictionary of Films, translated, edited, and updated by Peter Morris and published by the University of California Press, includes a description of Chapaev and the scene. The listing is online on Google Books: https://books.google.com/books?id=_CL5zCKR2PgC\& $\mathrm{pg}=\mathrm{PA} 59 \& \mathrm{lpg}=\mathrm{PA}_{59} \& \mathrm{dq}=\mathrm{chapaev}+$ psychological + attack \& source $=$ bl\&ots =EzcYq1nUQ\&sig=ACfU ${ }_{3}$ Uohcy-LCQbucw9kI 1 waveQl-fzA-g\&hl=en\&sa 
=X\&ved=2ahUKEwi8tPSal9fgAhUK7qwKHXveAGoQ6AEwAnoECAcQA $\mathrm{Q} \# \mathrm{v}=$ onepage\& $\mathrm{q}=$ chapaev\%2opsychological\%2oattack\&f=false.

2. The Krokodil piece is contained in The Soviet Government and the Jews, 19481967, ed. Benjamin Pinkus, Cambridge University Press, 1984. It is available online, through Google Books: https://books.google.com/books?id=V7 g8AAAAIAAJ\&pg $=\mathrm{PA} 135 \& \mathrm{lpg}=\mathrm{PA} 135 \& \mathrm{dq}=$ pinya + mirochnik \& source

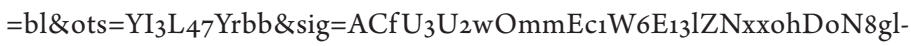
Q\&hl=en\&sa $=X \& v e d=2 a h U K E w j 4 \mathrm{mJH}_{5} q d f g A h V C j 1 \mathrm{kKHTpoAjIQ6AEwC}$ noECAgQAQ\#v=onepage \&q=pinya\%2omirochnik\&f=false 


\section{KLOTSVDG}


